\title{
Materials Research and Opportunities in Thermal (Coal-based) Power Sector Including Advanced Ultra Super Critical Power Plants
}

\author{
S C CHETAL ${ }^{1,2}$, T JAYAKUMAR ${ }^{1,2}$ and A K BHADURI ${ }^{1 *}$ \\ ${ }^{1}$ Indira Gandhi Centre for Atomic Research, Kalpakkam 603 102, Tamil Nadu, India \\ ${ }^{2}$ Presently: Honorary Scientific Consultant, Office of the Principal Scientific Adviser to the Government \\ of India, 326, Vigyan Bhavan Annexe, Maulana Azad Road, New Delhi 110 011, India
}

(Received on 30 March 2014; Accepted on 02 August 2015)

\begin{abstract}
The Integrated Energy Policy of the Government of India envisages an ambitious programme for power capacity addition to about 800 GWe by 2031-32 towards meeting the energy demands of the country for ensuring the required economic growth and improved standards of living. For minimizing carbon dioxide emissions, through achieving the highest possible energy efficiency and reducing coal required per unit of power generated, it is planned to adopt clean-coal-based power generation technologies such as supercritical, ultra-supercritical, advanced ultra-supercritical and integrated gasification combined cycle, which are in different stages of development, demonstration and commercialization worldwide. Certain innovative options such as carbon dioxide capturing and sequestration and high-temperature bio-waste and bio-fuel based plants are also being explored. This paper discusses the materials research and opportunities of these power generation technologies.
\end{abstract}

Keywords: Advanced Ultra Super Critical Technology; Power Plants; Materials; Indigenization; Boiler Tubes, Welding, Non-Destructive Evaluation; Integrated Gasification Combined Cycle; Bio-Waste, BioFuel

\section{Introduction}

Coal is India's main source of energy, with about $66 \%$ of power generation being dependent on coal. India's coal reserves are currently assessed at 286 billion tonnes, with proven reserves being about 114 billion tonnes (Coal India Limited, 2014). Among various energy sources for capacity addition in power in India, coal would continue to be the most predominant (more than 50\%) source of energy at least till the middle of the $21^{\text {st }}$ century. However, it is also a fact that coal is the single largest source of carbon dioxide emission through power generation, which is a cause of concern from the perspective of climate change. India therefore needs to adopt a cautious approach for using coal as the primary source of power generation. India desires to adopt clean coal-based power generation technologies that help minimize carbon dioxide emissions, while yielding the highest possible energy efficiency and reducing the coal required per unit of power generated. Thus, adoption of such technologies would also enhance energy security for the nation by increasing the longevity of coal reserves.

Several clean coal technologies have been and are being developed worldwide. These include supercritical, USC, Advanced Ultra Super-Critical (AUSC), Integrated Gasification Combined Cycle (IGCC) etc., which are in different stages of development, demonstration and commercialization. Besides, certain innovative options are also currently explored, albeit in small measures, in Carbon dioxide

*Author for Correspondence: E-mail: bhaduri@igcar.gov.in 
Capturing and Sequestration/storing (CCS) (Logan et al., 2007), just as any other power plant effluents are safely reposited. The CCS process involves capturing of carbon dioxide from power plants and other sources, transporting it to suitable locations and injecting it into geological reservoirs. While the technology of CCS for capture, transport and sequestration exists, the additional cost involved, environmental and safety issues are still concerns that need to be solved for a successful implementation of CCS as a successful industrial practice. The future options also include combining energy cycles such as Rankine (steam) and Brayton (gas), so as to reap an overall efficiency of about 60\% (Fig. 1) (Logan et al., 2007).

Several countries in the world are adopting increasing steam parameters in order to attain higher and higher efficiency and thus leading to lower and lower carbon dioxide emissions. Supercritical technology has already been adopted commercially worldwide and also in India. Supercritical power plants have higher steam cycle parameters than conventional sub-critical power plants, thus offering higher efficiency, consuming less coal per unit power produced and emitting less carbon dioxide per MWeh. In India, of the initial $660 \mathrm{MWe}$ supercritical power plants, with steam parameters of $247 \mathrm{~kg} / \mathrm{cm}^{2} / 537^{\circ} \mathrm{C} /$ $565^{\circ} \mathrm{C}\left(247 \mathrm{~kg} / \mathrm{cm}^{2}\right.$ main line steam pressure/ $537^{\circ} \mathrm{C}$ main line steam temperature $/ 565^{\circ} \mathrm{C}$ reheat line

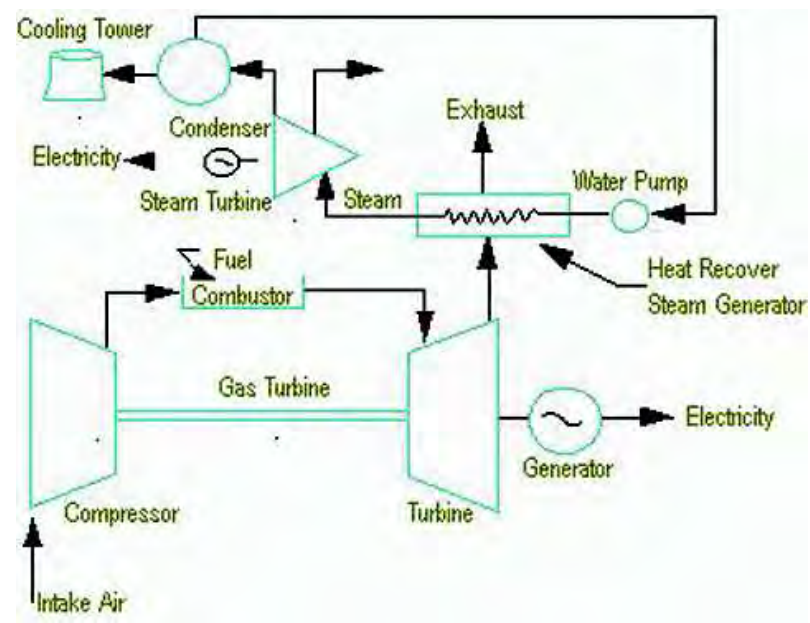

Fig. 1: Schematic of combined cycle power plant (Logan et al., 2007) steam temperature), a few have been commissioned. Subsequently, plants of 660 and 800 MWe units, with higher steam parameters of $247 \mathrm{~kg} / \mathrm{cm}^{2} / 565^{\circ} \mathrm{C} / 593^{\circ} \mathrm{C}$ are under construction.

In recent years, several pulverized coal-fired power plants with Ultra Super-Critical (USC) steam parameters (i.e., $\geq 250 \mathrm{~kg} / \mathrm{cm}^{2} / \geq 600^{\circ} \mathrm{C} / \geq 600^{\circ} \mathrm{C}$ ) have been set up or are under construction in Europe, Japan, China and Korea. These have higher efficiencies than supercritical power plants. Power plants with USC steam parameters are likely to be set up in India in the next few years, once the initial supercritical plants are in regular operation. Further, research and development $(R \& D)$ is in progress in USA, Europe and Japan on the AUSC cycle with steam parameters of $\geq 300 \mathrm{~kg} / \mathrm{cm}^{2} /=700^{\circ} \mathrm{C} /=700^{\circ} \mathrm{C}$. With such enhanced steam parameters, the efficiency of the power plant is expected to be in the range of $45-47 \%$ (gross on higher heating value basis) with Indian coal under Indian ambient conditions, with carbon dioxide mitigation potential in the order of $20-25 \%$ as compared to conventional sub-critical power plants (Table 1). It can be observed from Table 1 that the specific carbon dioxide emissions from an AUSC plant will be about $17 \%$ less than those from a typical sub-critical plant. Typically, for an 800 MWe AUSC plant, this will translate to a reduction in carbon dioxide emissions of about 1 million tons per year. Thus, the introduction of AUSC power plants can help reduce the carbon dioxide emission intensity of India, and this would enable India to address the issue of climate change even with continued reliance on coal with concomitant reduction in consumption of coal.

An ambitious programme for power capacity addition has been envisaged in India for meeting the energy demands of the country to ensure the required economic growth and improved standard of living through the introduction of supercritical and USC power plants. According to the Integrated Energy Policy of Government of India, the country needs an installed capacity of about 800 GWe by 2031-32 (Planning Commission, Government of India, 2006).

\section{Potential for AUSC Power Plants in India}

Considering the high and growing energy demand in 
Table 1: Efficiencies and carbon dioxide emissions from various types of plants

\begin{tabular}{lcccc}
\hline $\begin{array}{l}\text { Plant type } \\
\text { with power } \\
\text { rating }\end{array}$ & $\begin{array}{c}\text { Steam } \\
\text { pressure } \\
\left(\mathrm{kg} / \mathrm{cm}^{2}\right)\end{array}$ & $\begin{array}{c}\text { Steam } \\
\left({ }^{\circ} \mathrm{C}\right)\end{array}$ & $\begin{array}{r}\text { Efficiency } \\
(\%)\end{array}$ & $\begin{array}{c}\text { Carbon } \\
\text { dioxide } \\
\text { emissions } \\
(\mathrm{kg} / \mathrm{MWe} \text {-h })\end{array}$ \\
\hline $\begin{array}{l}\text { Sub-critical } \\
\text { plant (500 MWe) }\end{array}$ & 170 & $540 / 540$ & $35-38$ & 900 \\
$\begin{array}{l}\text { Super-critical } \\
\text { plant (660/800 MWe) }\end{array}$ & & & & \\
$\begin{array}{l}\text { Advanced ultra } \\
\text { super-critical plant } \\
(800 \text { MWe })\end{array}$ & 300 & $560 / 590$ & $40-42$ & 830 \\
\hline
\end{tabular}

the country, there is an excellent scope for setting up clean coal technology based AUSC power plants in India with reduced carbon dioxide emission. Under the National Mission Programme on Clean Coal (Carbon) Technologies, development of AUSC thermal power plants has been identified as one of the projects to be taken up on priority. This project is proposed to be executed in two phases. The objective of the first phase would be to undertake $R \& D$ on all aspects of AUSC technology for thermal power plants in order to improve power plant efficiency, reduce carbon dioxide emissions and reduce coal consumption per unit of power generated. In the second phase, an 800 MWe AUSC demonstration power plant will be established based mainly on the technology developed in the first phase. Once a first demonstration 800 MWe AUSC power plant is proven to be technologically successful, a large number of such plants can be designed with AUSC technology. This could mean a potential of as high as 10-15 units of 800 MWe sets per year. As technology matures with time, the unit ratings of sets could also go up, reducing the specific cost further.

\section{Developing AUSC Technology Indigenously - A Necessity}

In addition to pursuing indigenization efforts, India has been acquiring proven technologies in power generation and other areas from abroad. While acquiring technologies is easier and expeditious to implement, it should be noted that by and large only manufacturing and limited design information is transferred by foreign collaborators. This results in perpetual dependence on foreign suppliers and in the long run proves more expensive due to the continued dependence on import of key materials and technologies. For instance, the import content of the technology acquired in the early eighties for $500 \mathrm{MWe}$ sub-critical boiler turbine generator sets still continues to be as high as $30 \%$.

Technology acquisition in the present scenario also involves a high level of business sharing, which not only raises costs but also slows down the technology absorption process, and thus severely affecting the indigenization and potential savings of costs. For supercritical sets of 660 or 800 MWe rating, the import content is currently about $50 \%$, which will gradually decrease with time.

With indigenous development of AUSC technology, including indigenization of materials, the long-term import content would be significantly reduced. This will also reduce India's dependence on imports even for our existing fleet of coal-fired power plants. While development of the technology involves an upfront investment in $\mathrm{R} \& \mathrm{D}$, in the long run, it will prove to be much less expensive than acquiring the technology after a few years, of course with conditions attached for the imported technology. Import of equipment, once developed and commercialized abroad, has always proven to be expensive. Further, with continued dependence on imported technology, India's national priorities could be vulnerable to changes in the priorities and time schedules set by the technology developers, apart from their willingness to share such advanced technologies. Indigenous development of AUSC technology also has significant spin-off benefits in related industries, as it has happened in the case of space and nuclear sectors.

\section{Ultra Super-Critical Technology}

Any steam cycle unit with steam pressure greater than the critical point of $225 \mathrm{~kg} / \mathrm{cm}^{2}$ is said to be super-critical. There is no standard definition for USC power plants, and different parameters are being used in different parts of the world to categorize a power plant as a USC plant. However, as a common practice, 
any supercritical coal-based power plant having mainsteam temperature of $600^{\circ} \mathrm{C}$ or above has been considered as ultrasuper-critical. In addition, the steam pressure in USC plants is more than $250 \mathrm{~kg} / \mathrm{cm}^{2}$. The total number of supercritical coal-based power generation units globally is about 600 , of which about 60 are USC units. These USC power plants are in the capacity ranging from $350 \mathrm{MWe}$ to $1000 \mathrm{MWe}$. Brief information about some of these plants is given in Table 2.

\section{International Efforts in AUSC Technology Development}

The USC technology for steam parameters up to $280 \mathrm{~kg} / \mathrm{cm}^{2}$ and $600^{\circ} \mathrm{C}$ superheater/reheater temperatures can generally be considered as a mature technology in the world and is ready for adoption. In order to further improve the power plant efficiency and mitigate specific carbon dioxide emission, studies are currently being conducted in the European Union,

Table 2: Someultra super-critical (temperature $>593^{\circ} \mathrm{C}$; pressure $>250 \mathrm{~kg} / \mathrm{cm}^{2}$ ) installations

\begin{tabular}{|c|c|c|c|c|c|c|}
\hline S.No. & Name of power plant & Country & $\begin{array}{l}\text { Capacity } \\
\text { (MWe) }\end{array}$ & $\begin{array}{l}\text { Pressure } \\
\left(\mathrm{kg} / \mathrm{cm}^{2}\right)\end{array}$ & $\begin{array}{c}\text { Temperatures } \\
\left({ }^{\circ} \mathrm{C}\right)\end{array}$ & Year of operation \\
\hline 1. & Matsuura No. 2 & Japan & 1000 & 255 & $598 / 596$ & 1997 \\
\hline 2. & Haramachi No. 1 & Japan & 1000 & 245 & $600 / 600$ & 1997 \\
\hline 3. & Haramachi No. 2 & Japan & 1000 & 259 & $604 / 602$ & 1998 \\
\hline 4. & Nanaoota No. 2 & Japan & 700 & 255 & $597 / 595$ & 1998 \\
\hline 5. & Chougoku EPCo. & Japan & 1000 & 246 & $600 / 600$ & 1998 \\
\hline 6. & Tsuruga No. 2 & Japan & 700 & 255 & $597 / 595$ & 2000 \\
\hline 7. & Tachibana-Wan No. 1-2 & Japan & $2 \times 1050$ & 259 & $605 / 613$ & 2000 \\
\hline 8. & Misumi No. 1 & Japan & 600 & 250 & $605 / 600$ & 2001 \\
\hline 9. & Isogo No. 1 (J-Power) & Japan & 600 & 255 & $600 / 610$ & 2002 \\
\hline 10. & Isogo No. 2 & Japan & 500 & 245 & $600 / 600$ & 2002 \\
\hline 11. & Tomato-Atsuma No. 4 & Japan & 700 & 255 & $600 / 600$ & 2002 \\
\hline 12. & Neideraussen & Germany & 1000 & 290 & $580 / 600$ & 2002 \\
\hline 13. & Hitachinaka No. 1 & Japan & 1000 & 245 & $600 / 600$ & 2003 \\
\hline 14. & Maizuru No. 1 & Japan & 900 & 245 & $595 / 595$ & Under construction \\
\hline 15. & Hirono No. 5 & Japan & 600 & 245 & $600 / 600$ & Under construction \\
\hline 16. & Shandong Zouxian & China & $2 \times 1000$ & 250 & $600 / 600$ & 2006 \\
\hline 17. & Torrevaldaliga & Italy & $6 \times 660$ & 250 & $600 / 610$ & 2006 \\
\hline 18. & Yuhuan No. 1-4 & China & $4 \times 1000$ & 268 & $600 / 600$ & 2006-2007 \\
\hline 19. & Zouxian No. 4,7-8 & China & $3 \times 1000$ & 241 & $600 / 600$ & $2006-2007$ \\
\hline 20. & Wai Gao Qiao No. 3-4 & China & $2 \times 1000$ & 275 & $600 / 600$ & $2007-2008$ \\
\hline 21. & Jiangsu Taizhou No. 1-2 & China & $2 \times 1000$ & 255 & $600 / 600$ & 2007 \\
\hline 22. & Neurath No. 1-2 & Germany & 1100 & 295 & $600 / 605$ & 2008 \\
\hline 23. & Westfalen & Germany & $2 \times 800$ & 275 & $600 / 610$ & 2011 \\
\hline 24. & Eemshafen & Netherlands & $2 \times 800$ & 275 & $600 / 610$ & 2012 \\
\hline 25. & Luenen & Germany & $1 \times 800$ & 270 & $600 / 610$ & 2012 \\
\hline 26. & Mainz & Germany & $1 \times 800$ & 273 & $600 / 610$ & 2013 \\
\hline
\end{tabular}


USA and Japan for use of steam parameters of $300 \mathrm{~kg} / \mathrm{cm}^{2}$ and more pressure and $700^{\circ} \mathrm{C}$ and more steam temperatures (Table 3 ). These conditions have been termed as AUSC to distinguish them from the USC plants that are being already considered worldwide. In this context, for India, AUSC plants with steam parameters of $310 \mathrm{~kg} / \mathrm{cm}^{2}$ and steam temperatures of $710^{\circ} / 720^{\circ} \mathrm{C}$ are being considered.

Table 3: Steam parameters being considered for AUSC plants in different countries

\begin{tabular}{lccc}
\hline Year (start) & Country & $\begin{array}{c}\text { Temperature } \\
\left({ }^{\circ} \mathrm{C}\right)\end{array}$ & $\begin{array}{c}\text { Pressure } \\
\left(\mathrm{kg} / \mathrm{cm}^{2}\right)\end{array}$ \\
\hline 1990 & USA & 760 & 350 \\
1998 & Europe & 700 & 350 \\
2007 & China & 700 & 300 \\
2008 & Japan & 700 & 350 \\
2010 & India & $710 / 720$ & 310 \\
\hline
\end{tabular}

\section{Efforts by the European Union}

The European Union has supported efforts on increasing the steam parameters of power plants by co-financing research projects COST, AD700 and COMTES700 (Klenk et al., 2010), targeting materials development, manufacturing, testing, evaluation and demonstration employing test loops in existing power plants. A consortium of utilities, equipment manufacturers, materials manufacturers, universities and research institutions has participated in these programmes. For example, the main tasks of AD700 programme were as follows (Klenk et al., 2010).

(i) Demonstration of nickel-base super-alloys for long-term operation in the temperature range of $700-720^{\circ} \mathrm{C}$.

(ii) Development of new fabrication methods for components made of super-alloys.

(iii) Development of new austenitic steels for boiler tubes operating in the temperature range of 600$700^{\circ} \mathrm{C}$ to minimize the use of the expensive super-alloys.

(iv) Investigation of corrosion resistance of the new alloys operating at $700-750^{\circ} \mathrm{C}$
The AD700 Project was realized in different phases. The first phase focused on the development and mechanical testing of new materials, development of new furnace designs, and techno-economic study regarding the economic viability of the new plant concept. The second phase included demonstration of manufacture of new materials, design of component test facility and preparatory work for the demonstration phase. The third phase included demonstration of developed materials in two smallscale test installations under the COMTES700 project (Klenk et al., 2010). The main objective of the COMTES700 project has been the demonstration of the new materials in a component test facility at a German power plant and in a small test rig in a Danish power plant. The testing period of the components has been approximately 20,000 hours, spread over a period of more than four years starting from 2005. A further component test programme ENCIO has been initiated to test the creep behaviour of thick crosssection components at a power plant in Italy. It was expected that the design of an AUSC power plant can start by 2015 , with the operation of the first demonstration plant by 2020 (Klenk et al., 2010).

\section{Efforts by the USA}

US DOE has launched and co-funded a National Project "Vision 21 Power Plants" for developing new materials with USC steam parameters, along with EPRI and a consortium of power equipment manufacturers (Viswanathan et al., 2005). The goals of the research program are as follows.

(i) Identification of the materials performance issues that limit the operating temperatures.

(ii) Identification of improved alloys, fabrication processes and coating methods that will permit boiler operation at steam temperatures up to $760^{\circ} \mathrm{C}$ and steam pressures up to $378 \mathrm{~kg} / \mathrm{cm}^{2}$.

(iii) Definition of issues impacting designs that can permit power generation at temperatures greater than or equal to $870^{\circ} \mathrm{C}$.

The first phase has been completed. Alloy $740 \mathrm{H}$ was identified as the most suitable material. In the next phase, efforts are on to identify a power plant 
where components can be tested in actual conditions. This phase is likely to be completed by 2020 . Subsequently, a demonstration plant is expected to be set up.

\section{Efforts by Japan}

The Japanese government launched the "Cool EarthInnovative Energy Technology Program" in 2008 to promote international cooperation and actively contribute to substantial reduction in global greenhouse gas emissions. Twenty-one technologies that can contribute to substantial reductions in carbon dioxide emissions by efficiency improvement and low carbonization were selected. A $700^{\circ} \mathrm{C}$ class boiler, turbine and valve technologies, including hightemperature materials technology, are being developed. The aim is to commercialize $700^{\circ} \mathrm{C}$ class pulverized coal power system with efficiency of $46 \%$ by 2015 and $48 \%$ by 2020 . Candidate materials for boilers are being tested, and turbine rotor and casing materials are being developed and tested. Steam power plants that have been built recently usually have $250 \mathrm{~kg} / \mathrm{cm}^{2} / 600^{\circ} \mathrm{C}$ steam conditions. By developing $700^{\circ} \mathrm{C}$ class AUSC from the latest $600^{\circ} \mathrm{C}$ class USC, carbon dioxide emissions can be reduced by more than $10 \%$. In addition to efficiency improvement, biomass co-firing and carbon dioxide recovery technology will be adopted to reduce carbon dioxide emissions further. A double reheat system with the steam condition of $350 \mathrm{~kg} / \mathrm{cm}^{2}$ main steam pressure, $700^{\circ} \mathrm{C}$ main steam temperature and $720^{\circ} \mathrm{C}$ reheat temperature can achieve the thermal efficiency of $46 \%$ (high heating value basis). The National Institute of Materials Science (NIMS) and leading power equipment manufacturers are associated in the program.

\section{Efforts by China}

The first application of supercritical boilers in China was in 1992 ( $2 \times 600$ MW units at Shidongkou). Supercritical and USC units began to be installed in 2002 and have expanded very fast since then; with more than 150 supercritical and USC units with $600 \mathrm{MW}$ or higher capacity in operation or under construction. In December 2004, China's first domestically built 600 MW SC unit of Qinbei Power
Plant was put into operation. The $4 \times 1000$ MW Yuhuan Power Plant is China's first commercially operated power plant using domestically built 1000 MW USC pressure boilers $\left(240-275 \mathrm{~kg} / \mathrm{cm}^{2} / 600^{\circ} \mathrm{C}\right.$ superheater/ reheater steam; $46 \%$ net efficiency) during 2006 to 2008; 2×1000 MW USC units at Zouxian Power Plant went into operation during December 2006 to July 2007; 4×1000-MW USC power units have been commissioned since end of 2007. During 2008-2009, 6 sets of imported and 50 sets of indigenous 1000MW USC power units $\left(250 / 263 \mathrm{~kg} / \mathrm{cm}^{2}, 600^{\circ} \mathrm{C} / 600\right.$ ${ }^{\circ} \mathrm{C}$ ) were ready and more than 90 sets of $600-\mathrm{MW}$ USC power units were planned to be commissioned.

By 2010, supercritical and USC units accounted for over $40 \%$ of the total newly built thermal power generating units. By end of 2008, $90 \mathrm{GWe}$ of supercritical and 11.2 GWe USC units were in operation and more than $100 \mathrm{GWe}$ of supercritical and USC units were under construction. China's top three power equipment producers, Dongfang Electric, Harbin Electric and Shanghai Electric, have imported the manufacturing technology for supercritical and USC plants. From 2010 to 2020, new power plants with unit capacities of $600 \mathrm{MW}$ and more will be supercritical units and about half of the newly built power generating units will be USC units. Consequently, supercritical units would have accounted for over $15 \%$ of the total power capacity by 2010 and $30 \%$ by 2020 . China has also initiated programmes for development of AUSC technology.

In the next 15 years, several measures will be undertaken in China's power industry. These would include (i) constructing large-capacity power units, retrofitting old power units, shutting down small-sized power units, developing cogeneration units, optimizing unit operation, and applying new technologies for energy conservation to improve the efficiency of coalfired power generation; (ii) applying high-efficiency dust-separation technology and new FGD/de- $\mathrm{NO}_{\mathrm{x}}$ techniques to reduce the pollutant emission from thermal power plants; (iii) using an air-cooling technology for water conservation; (iv) actively introducing and developing large-capacity supercritical power units; and promoting clean coal power generation (Yongping et al., 2010). 


\section{Development of AUSC Technology in India}

Supercritical power plants currently under construction and being planned in the country are either being supplied by foreign companies or are being manufactured by Indian companies through various collaborations under which technology is being provided by the foreign collaborator. Various strategies have been considered for transfer of know-how of supercritical technology to India. Foreign manufacturers are also setting up their manufacturing base in India, thus ensuring that the technology remains in their hands.

The above approach would ensure large-scale penetration and utilization of supercritical technology in India. However, in order to further improve the power plant efficiency, to mitigate carbon dioxide emissions, for reduced use of coal per MWe, and considering huge capacity addition through coal power generation, it is essential that indigenous AUSC power plants are adopted if the country has to reap the benefits of indigenous technology. It can be concluded from the international efforts that AUSC plants having $300 \mathrm{~kg} / \mathrm{cm}^{2} / 700^{\circ} \mathrm{C}$ or above steam cycle parameters are being designed by a few countries. However, it should be borne in mind that no mature, off-the-shelf technology is available for such plants. Materials for use at temperatures up to and above $700^{\circ} \mathrm{C}$ are being used in many Indian industries except in the thermal power sector. Considering India's ambitious capacity addition programme, which will be largely based on coal as the source of energy up to about 2050, it is most opportune that India develops its own AUSC technology, which will not only go a long way in serving its own needs but also could be a major source for meeting global requirements.

Recognizing that the country has planned installation of a large number of supercritical plants of 800 MWe capacity plants, it is prudent to select 800 MWe rating for an indigenous AUSC demonstration plant. Development efforts needed for smaller unit of 660 MWe would be no different than that for $800 \mathrm{MWe}$ plant and unit energy cost would also be higher for smaller units.
The materials choice for steam temperature of about $700^{\circ} \mathrm{C}$ is well-documented. From the objectives of higher plant efficiency of at least $46 \%$, resulting carbon dioxide mitigation and reduced amount of coal per MWe, steam parameters of $310 \mathrm{~kg} / \mathrm{cm}^{2}$ and $710^{\circ} \mathrm{C}$ and $720^{\circ} \mathrm{C}$ as the main steam and reheat steam temperatures, respectively, have been selected for detailed design (Fig. 2).

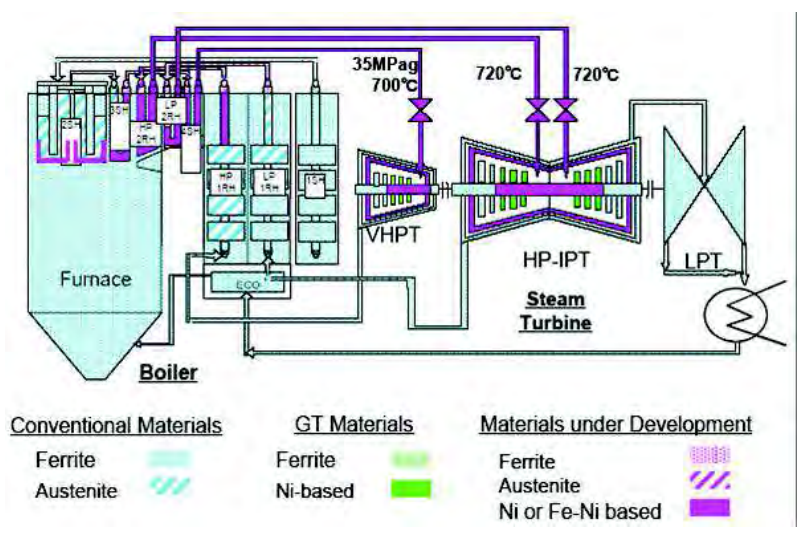

Fig. 2: Schematic layout of the proposed Indian AUSC plant(Jayakumar et al., 2014)

\section{Overview of Development Approach for AUSC Technology -Indian Perspective}

\section{Selection of Materials and R\&D for AUSC Power Plants}

Selection of superheater and reheater materials, manufacturing technology and equipment development constitute important areas to be addressed while considering the $710^{\circ} / 720^{\circ} \mathrm{C}$ steam cycle. It is important to note that a large $710^{\circ} / 720^{\circ} \mathrm{C}$ AUSC plant will have materials in some of the components similar to the mature sub-critical units in the country. These components include condenser, feed-water heaters, water pumps and feed-water piping. The boiler will have different materials for waterwall and superheater zone, with each material optimized according to steam temperature and pressure conditions. The materials for the waterwall and the first-stage of superheater and reheater boiler tubing can be adopted from the current USC power plants of $600^{\circ} \mathrm{C}$ steam temperature. Advanced materials need to be developed only for the top-end of superheater and 
reheater boiler tubing, main steam and hot reheat piping, high-pressure and intermediate-pressure stop and control valves, high-pressure and intermediatepressure turbine, and turbine integral piping for the AUSC plants of $710^{\circ} / 720^{\circ} \mathrm{C}$ steam temperature. The turbine design can be modular in nature, with the turbine being designed with changes in the highpressure and intermediate-pressure portions to suit the higher steam parameters.

One of the most critical aspects in the development of AUSC technology is the choice of materials for high temperature zones. The criteria for selection of materials for different components of the AUSC plant should be based, apart from their physical properties, on their inclusion in ASME Code or Code Case or equivalent international code. This would ensure that there is a strong basis for design of components and wide commercial availability of materials. Additionally, the materials for the AUSC plants of $710^{\circ} / 720^{\circ} \mathrm{C}$ steam temperature would have to be selected for different components based on: (a) adequate high temperature mechanical strength, viz. average stress to rupture of $100 \mathrm{MPa}$ for 100,000 hours at design temperature of component; (b) high thermal conductivity and low thermal expansion coefficient to minimize thermal stresses; (c) good formability and weldability; (d) satisfactory corrosion resistance in steam and flue gas environment; (e) moderate creep-fatigue interaction; (f) industrial availability/confidence in indigenous development; and, (g) economy. The relatively new materials that are proposed to be used in the AUSC plants include the following.

(1) Grade-23 steel (2.25Cr-1.6W-V-Nb-B, as per ASME code case 2199) for water walls;

(2) Grade-91 steel (9Cr-1Mo-V-Nb-N, as per ASME SA-213) for superheater and reheater tubing.

(3) $304 \mathrm{HCu}$ austenitic stainless steel $(18 \mathrm{Cr}-9 \mathrm{Ni}-$ $3 \mathrm{Cu}-\mathrm{Nb}-\mathrm{N}$, as per ASME code case 2328) for the final stage of superheater tubing, in which the finely dispersed spherical copper precipitates (of $32 \mathrm{~nm}$ size) are highly stable in the austenite matrix even after long-term ageing upto $10,000 \mathrm{~h}$ at $650^{\circ} \mathrm{C}$ (Bai et al., 2013).
(4) Nickel-base Alloy 617 (52Ni-22Cr-13Co-9Mo, as per ASME SB-167 specification), with controlled composition (Alloy 617M) for the final stage of superheater and reheater tubing at the hottest zone, with the higher requirements of A617M including notably stringent limitations on elements such as C, B, Cr, Ti, Fe, Si and Mn, and a solution annealing temperature higher than $1160^{\circ} \mathrm{C}$.

Any other material, such as Alloy $740 \mathrm{H}$ (Ni25Cr-20Co as per ASME code case 2702) and Sanicro-25 (X7NiCrWCuCoNbB25-23-3-3-2 as per VdTüV 555), with promising mechanical properties, should also be examined for suitable applications. The extent of use of these materials will depend on the optimisation studies of cost-benefit in the hot regime of the boiler. The preferred materials for the highpressure and intermediate-pressure turbine parts, viz. rotor, blades, valves, casings etc., would be Alloy $617 \mathrm{M}$ for the wrought products and Alloy 625 for the cast products. However, extensive equipment manufacturing technology development would have to be adopted. For development of materials and manufacturing technology, a pragmatic approach would have to be adopted considering the existing industrial base and pace at which industrial capabilities can be enhanced. Industrial base exists in the country for boiler tubing, and can be extended for piping, pipe fittings and valves. Wherever possible, efforts have to be made to indigenously produce advanced materials and manufacture components based on these materials developed indigenously. The chemical compositions of the candidate materials for the AUSC plants are provided in Table 4. The allowable stresses (as per ASME) as a function of temperature for the different candidate AUSC boiler materials is given in Fig. 3A, while that for Alloy 617M is given in Fig. 3B (Dietz et al., 2009). In this regard, it is important to mention that the design temperature of the tube mid-wall will be $40^{\circ} \mathrm{C}$ higher than the steam temperature.

With the initiative and funding from the Office of the Principal Scientific Adviser (PSA) to the Government of India, a beginning has already been 
Table 4: Chemical compositions (in wt. \%) of candidate materials for AUSC plants

\begin{tabular}{|c|c|c|c|c|c|c|}
\hline Element & $\begin{array}{c}\text { T23 } \\
\text { (ASME) }\end{array}$ & $\begin{array}{c}\text { T91 } \\
\text { (ASME) }\end{array}$ & $\begin{array}{c}\text { 304HCu SS } \\
\text { (ASME) }\end{array}$ & $\begin{array}{l}\text { Alloy } 617 \\
\text { (ASME) }\end{array}$ & $\begin{array}{c}\text { Alloy } 617 \\
\text { (VdTüV 485) }\end{array}$ & Alloy $617 \mathrm{M}$ \\
\hline Carbon & $0.04-0.10$ & $0.07-0.14$ & $0.07-0.13$ & $0.05-0.15$ & $0.05-0.10$ & $0.05-0.08$ \\
\hline Manganese & $0.10-0.60$ & $0.30-0.60$ & $1.00 \max$ & $1.0 \max$ & $0.7 \max$ & $0.3 \max$ \\
\hline Phosphorous & $0.03 \max$ & $0.02 \max$ & $0.040 \max$ & $0.015 \max$ & $0.012 \max$ & $0.012 \max$ \\
\hline Sulphur & $0.01 \max$ & $0.01 \max$ & $0.010 \max$ & $0.015 \max$ & $0.008 \max$ & $0.008 \max$ \\
\hline Silicon & $0.50 \max$ & $0.20-0.50$ & $0.30 \max$ & $1.0 \max$ & $0.7 \max$ & $0.3 \max$ \\
\hline Nickel & - & $0.40 \max$ & $7.50-10.50$ & $44.5 \min$. & Balance & Balance \\
\hline Chromium & $1.90-2.60$ & $8.50-9.50$ & $17.00-19.00$ & $20.0-24.0$ & $20.0-23.0$ & $21.0-23.0$ \\
\hline Molybdenum & $0.05-0.30$ & $0.85-1.05$ & - & $8.0-10.0$ & $8.0-10.0$ & $8.0-10.0$ \\
\hline Cobalt & - & - & - & $10.0-15.0$ & $10.0-13.0$ & $11.0-13.0$ \\
\hline Copper & - & - & $2.50-3.50$ & $0.5 \max$ & - & $0.5 \max$ \\
\hline Niobium & $0.02-0.08$ & $0.06-0.10$ & $0.30-0.60$ & - & - & - \\
\hline Titanium & - & $0.01 \max$ & - & $0.6 \max$ & $0.2-0.5$ & $0.3-0.5$ \\
\hline Tungsten & $1.45-1.75$ & $0.02 \max$ & - & - & - & - \\
\hline Vanadium & $0.20-0.30$ & $0.18-0.25$ & - & - & - & - \\
\hline Nitrogen & $0.03 \max$ & $0.03 \max$ & $0.05-0.12$ & - & - & $0.05 \max$ \\
\hline Aluminum & $0.03 \max$ & $0.07 \max$ & $0.003-0.030$ & $0.8-1.5$ & $0.6-1.5$ & $0.8-1.3$ \\
\hline Boron & $0.0005-0.006$ & - & $0.001-0.010$ & $0.006 \max$ & - & $0.002-0.005$ \\
\hline Iron & Balance & Balance & Balance & $3.0 \max$ & - & $1.5 \max$ \\
\hline
\end{tabular}

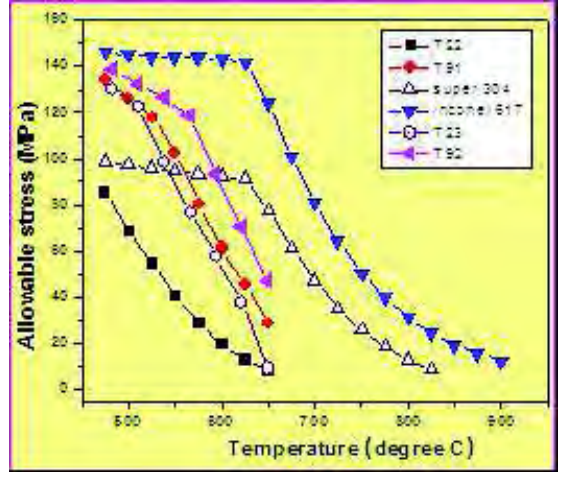

A

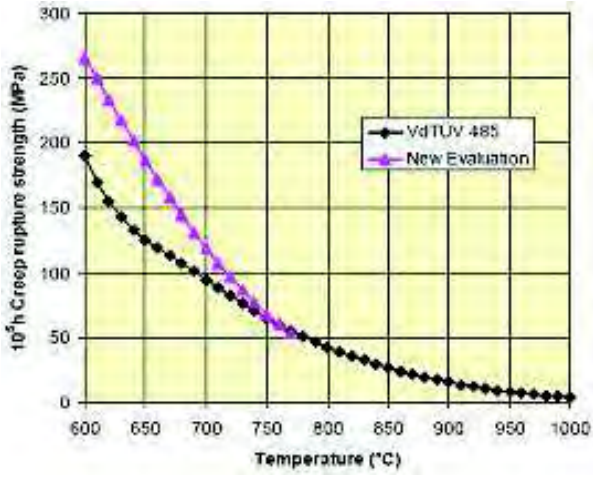

B

Fig. 3: Allowable stresses as a function of temperature of (A) different AUSC boiler materials, and (B) Alloy 617M ("New Evaluation") (Jayakumar et al., 2014)

made through the launching of the pre-project R\&D for the Development of Boilers with Advanced High Temperature Materials by a three-organization consortium of Indira Gandhi Centre for Atomic Research, Bharat Heavy Electricals Limited and NTPC Limited. This pre-project R\&D activity has, 
within a time frame of 2 years, led to the indigenous development and production of $52 \mathrm{~mm}$ diameter boiler tubes of $304 \mathrm{HCu}$ stainless steel of $9.5 \mathrm{~mm}$ wall thickness (Fig. 4) and Alloy 617M of $11.9 \mathrm{~mm}$ wall thickness, and their matching composition welding consumables, in collaboration with Mishra Dhatu Nigam Limited and Nuclear Fuel Complex. Appropriate welding procedures have also been developed for similar and dissimilar weld joints for the $304 \mathrm{HCu}$ stainless steel (Fig. 5) and Alloy 617M tubes. Evaluation of the mechanical properties (tensile, short-term creep, low-cycle fatigue, impact, quasistatic fracture and fatigue crack growth) of these two high-temperature tube materials and their weld joints indicates that their mechanical properties are comparable to the internationally reported values as also the codified values in the VdTÜV (German) standard.

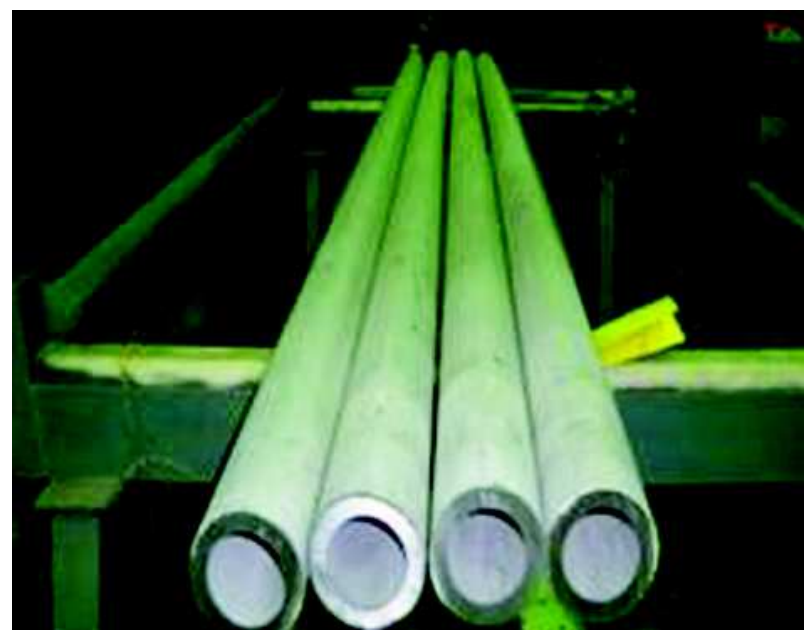

Fig. 4: Indigenously manufactured 304HCu SS boiler tubes of 6-7 m length (Jayakumar et al., 2014)

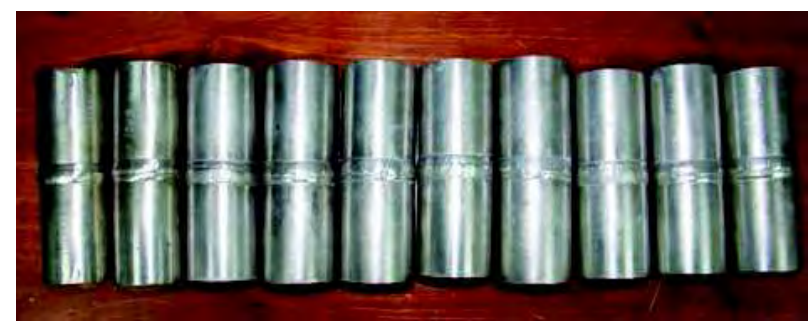

Fig. 5: Welded boiler tubes of indigenous $304 \mathrm{HCu}$ SS (Jayakumar et al., 2014)

\section{Development of Major Equipment}

The development approach for each of the major subsystems and equipment for the AUSC power plant would have to be based on analysis at the generic level, and the knowledge, skills and facilities available. Current capabilities in the country, together with additional skills that would be developed within the next few years during the execution of ongoing 660/ 800 MWe sub-critical boilers, would enable the full range of capabilities required to develop the boiler for an 800 MWe AUSC power plant.

Augmentation is needed for turbines, in particular, towards indigenous design capability, production of forgings in nickel-base Alloy 617M, castings in nickel-base Alloy 625 and welding technology for welded-rotor for HP and IP turbine, for an economic design. The turbine poses the biggest challenge for economic realization of AUSC plants both in India and abroad.

\section{Design Criteria, Codes and Standards}

The current Indian Boiler Regulations do not address comprehensively the design, materials, inspection, etc. relevant to AUSC components. Hence, there is a need to develop specific design criteria, codes and standards for the AUSC power plant components. Accordingly, design rules following the philosophy of "design by formula" as given in ASME codes would have to be used for the preliminary assessment of thickness of pressure boundary components. Further, the design would be confirmed by "design by analysis" accounting for the effects of thermal stresses, discontinuity stresses, namely thermal fatigue, ratcheting, etc., adopting the practices followed in the design of the nuclear components (liquid metal and gas cooled reactors). Due consideration would have to be given to evolving design rules recommended in German (VdTÜV), French (RCC-MR) and British (CEGB-R5 and R6) codes or any other relevant international codes. A few aspects, introduced as special rules specific to structural materials, would be validated by experimental benchmark tests on specimens having component features. It would definitely be a challenge to evolve robust state-ofthe-art design with advanced materials to ensure high 
confidence in design, manufacture and operation.

\section{Advanced Non-destructive Evaluation Techniques and Online Damage Assessment}

Technology for the non-destructive evaluation (NDE) during manufacture is available and the rules have been defined in codes of practice such as ASME. Nevertheless, pre-service inspection records are required to be generated to assess the performance during operation and life extension. From the in-service inspection point of view, reliability centred maintenance, quantitative risk-based inspection programs and condition-based maintenance to manage the systems will assume greater significance. Ultimately, the results of non-destructive testing need to be combined with issues of critical flaw size, fracture mechanics, probability of failure and acceptable level of risk for optimizing inspection schedules and extending plant life. Many of the components of AUSC power plants will be subjected to service conditions that lead to high levels of stresses, creep, fatigue and creep-fatigue interaction, and varied extent of fire-side corrosion and steam oxidation. Therefore, special attention would have to be given for development of on-line monitoring and inspection methodologies to assess life-limiting aspects (e.g. material degradation, creep-fatigue damage, etc.) and thereby improve plant availability. For this purpose, capability exists in the country but significant developmental efforts are needed. Some of the areas which need attention include design and development of high-temperature sensors, techniques and procedures for early-damage detection, online monitoring and continuous life-prediction methods, non-contact and global area monitoring, NDE modelling, signal analyses and image-processing techniques for enhanced sensitivity and quantitative NDE.

\section{Testing and Validation}

Testing of indigenously developed components in appropriate locations of operating power plants and in newly created dedicated test facilities/loops to assess the performance and validate the design and technology would have to be also taken up. It may be noted here that such challenges are being faced internationally in the development of materials and manufacturing of components for AUSC plants.

\section{Challenges and Current Capabilities in India for AUSC Technology}

The indigenous development of AUSC power plant technology is very challenging on account of the following reasons:

(i) AUSC technology has yet not been fully developed anywhere in the world.

(ii) New nickel-base alloys are required for which manufacturing technologies such as welding, manufacture of tubes and pipes, castings and forgings, are yet to be fully established. Commercial scale manufacturing facilities in the sizes and volumes required are not available anywhere in the world. In India, facilities for manufacture of such items even for supercritical plants are not available.

(iii) Equipment such as boilers and steam turbines has not been developed $a b$ initio in India so far.

Although the task is challenging, there is confidence that India has well-established capabilities for development of the AUSC power plant technology. With the objective of enhancing plant efficiency and/ or reducing the cost, further innovations in plant design would have to be considered and adopted, if found to be feasible, in terms of cost vis-à-vis benefit, reliability, and complexity in design, manufacture, layout and operations.

\section{Issues involved with Materials Development of AUSC Technology}

Development of AUSC technology in the country would essentially require the following.

(i) Forgings for turbines in nickel-base Alloy $617 \mathrm{M}$

(ii) Thick piping header in Alloy 617M/Cr-Mo steels

(iii) Economic route for production of boiler tubes in different grades

(iv) Development of forming, welding, and other manufacturing processes/capabilities. 
(v) Welded rotor technology of Alloy $617 \mathrm{M} / 10 \mathrm{Cr}-$ Mo steel for HP and IP turbines

\section{Gaps in the Development of AUSC Technology}

The Indian AUSC power plant development project would have to aim at development of ab initio equipment and component design. Such an approach has not been followed so far even for sub-critical plants, where designs had been developed through technology transfer/collaborative route. Also, the materials are largely imported for these plants. The indigenous design, materials, manufacturing and erection of 800 MWe AUSC plant would be a challenging and rewarding mega-initiative for India. The expertise available in the Indian industries, $R \& D$ organizations and academic institutions would need to be pooled and synergized, as detailed below, to realize the indigenous USC plant.

(i) Selection of materials and development of materials to incorporate in the indigenous plant, based on detailed materials testing and evaluation in existing plants under simulated conditions and/or in specific testing facilities will be another mega-challenge. In particular, testing under simulated conditions will be crucial to qualify the advanced materials. For this purpose, existing power plants would have to innovatively incorporate while new power plants should have provisions for testing of the new materials. Adequate testing, evaluation and characterization facilities would have to be established after due consideration of availability of existing facilities and expertise.

(ii) Development of material technology for wrought and cast products, forming and machining processes, welding consumables, and welding processes, along with necessary facilities and capacity additions, will be an important manufacturing challenge.

(iii) While a few facilities are available for material testing (for creep and fatigue), testing of a variety of AUSC materials at elevated temperatures of $750^{\circ}-800^{\circ} \mathrm{C}$ to provide shortterm material creep data simulating $710^{\circ} / 720^{\circ} \mathrm{C}$ steam plant design conditions requires enhancement of testing facilities dedicated to development of AUSC technology.

\section{Integrated Gasification Combined Cycle}

The integrated gasification combined cycle (IGCC) is a technology that uses a gasifier to turn coal and other carbon-based fuels into synthesis gas (syngas) from which pollutants such as sulphur are removed before the syngas is combusted, thereby lowering emissions of sulphur dioxide, particulates, etc. With additional process equipment, the carbon in the syngas can be shifted to hydrogen via the water-gas shift reaction resulting in nearly carbon-free fuel, with the carbon dioxide from reaction being amenable to compression and storage. Excess heat from the primary combustion and syngas-fired generation is passed to a steam cycle resulting in improved efficiency compared to that from conventional pulverized coal. The lower emissions that IGCC technology allows, in comparison to conventional power plants, would be important as emission regulations are tightened due to growing concern for impact of pollutants on the environment. The gasification process can produce syngas from a wide variety of carbon-containing feed-stocks such as highsulphur coal, heavy petroleum residues and biomass. The type of plant is called "integrated" because the syngas produced in the gasification section is used as fuel for the gas turbine in the combined cycle, and the steam produced by the syngas coolers in the gasification section is used by the steam turbine in the combined cycle. In a normal combined cycle, socalled "waste heat" from the gas turbine exhaust is used in a heat recovery steam generator to produce steam for the steam turbine cycle. An IGCC plant (Fig. 6) improves the overall process efficiency by using the higher-temperature steam produced by the gasification process in a steam turbine cycle to generate additional electrical power (Maurstad, 2005).

IGCC is now considered as "capture ready" and could potentially capture and store carbon dioxide. Around 30 IGCC plants are in operation around the world with electrical output of up to $300 \mathrm{MW}$ with a cumulative operating experience of over one million 


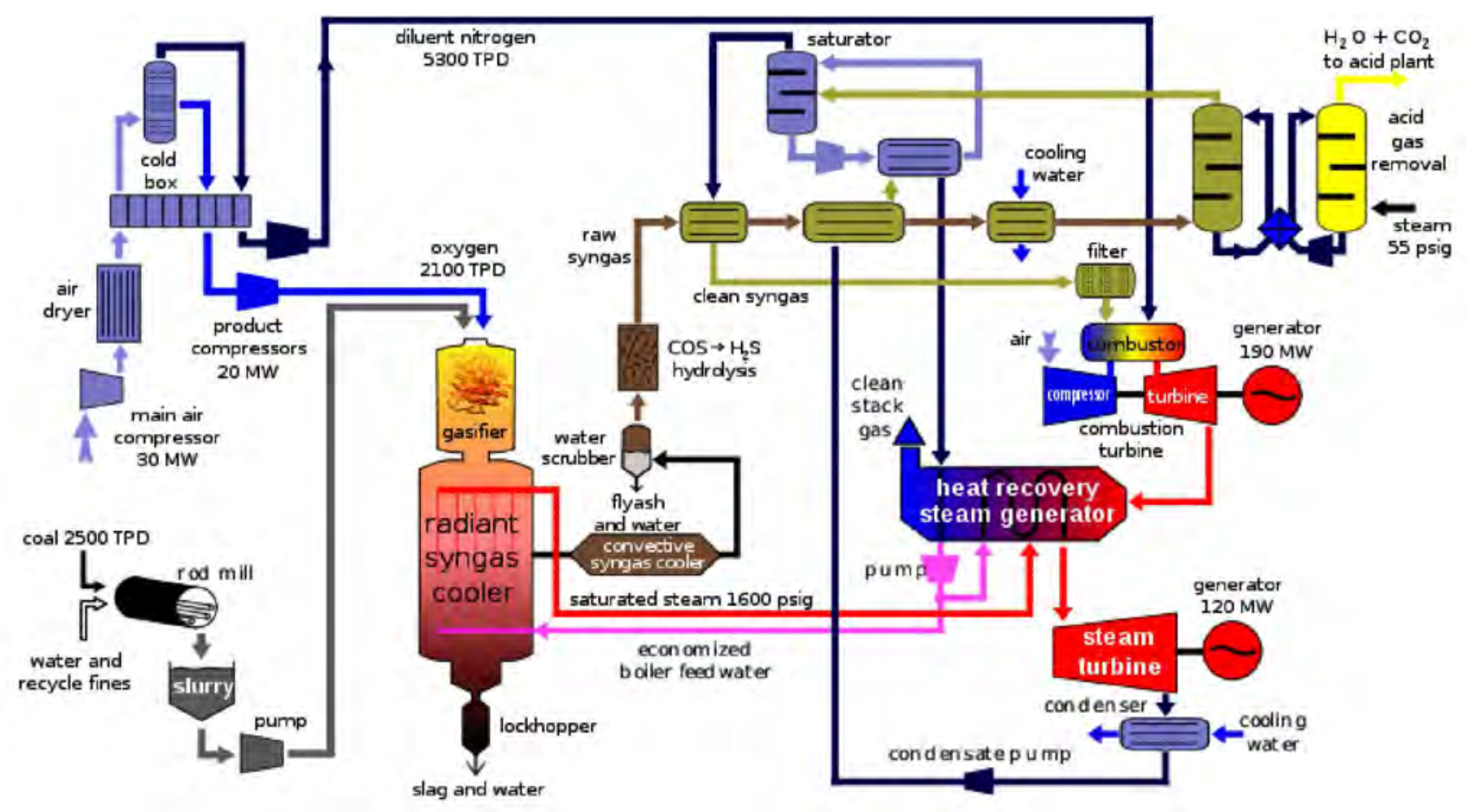

Fig. 6: Schematic of an IGCC power plant (Maurstad, 2005)

hours. In Tiruchchirappalli, India, a 6.2 MWe experimental coal gasification plant has been in operation for over 15 years. Efforts to set up a larger demonstration plant have not materialized due to unfavourable cost economics and lack of full-funded government support. There are several refinery-based IGCC plants in Europe that have demonstrated good availability (90-95\%) after initial shakedown periods. The following factors are responsible for their poor / limited performance.

(i) None of these facilities use advanced technology gas turbines.

(ii) All refinery-based plants use refinery residues, rather than coal, as the feedstock. This eliminates coal handling and coal preparation equipment and associated problems. Also, there is a much lower level of ash produced in the gasifier, which reduces cleanup and downtime in its gas cooling and cleaning stages.

(iii) These non-utility plants have recognized the need to treat the gasification system as an upfront chemical processing plant, and have reorganized their operating staff accordingly.

The high cost of IGCC is the biggest obstacle to its integration in the power market; however, most energy executives recognize that carbon regulation is coming soon. With carbon capture, the cost of electricity from an IGCC plant would increase approximately by $30 \%$. For a natural gas combine cycle, the increase is approximately $33 \%$. For a pulverized coal plant, the increase is approximately $68 \%$. Thus, the potential for less expensive carbon capture makes IGCC an attractive choice for keeping low cost coal as an available fuel source in a carbon constrained world.

Next generation IGCC plants with carbon dioxide capture technology will be expected to have higher thermal efficiency and to hold the cost down because of simplified systems compared to conventional IGCC. The main feature of these next generation plants is that, instead of using oxygen and nitrogen to gasify coal, they use oxygen and carbon dioxide. The main advantage is that it is possible to improve the performance of cold gas efficiency and 
to reduce the unburned carbon (char). The carbon dioxide extracted from the gas turbine exhaust gas can also be utilized. Use of a closed gas turbine system capable of capturing the carbon dioxide by direct compression and liquefaction obviates the need for having a separation and capture system.

\section{High-Temperature Bio-Waste and Bio-Fuel- based Plants}

Bio-fuel is most commonly defined as a renewable source of energy, which is produced from biological material or biomass, such as sugarcane, corn, cellulose or vegetable oils. The strategic goal of bio-fuel is to supplement or even replace fossil fuel which is constantly and rapidly diminishing in quantity. The most common types of bio-fuel these days are ethanol and bio-diesel. It is interesting to note that certain traditional fossil fuels, for example coal, may also be treated as a kind of bio-fuel since coal also originates from biological material.

Used-oil recycling is one of the ways to generate bio-fuel energy. Another method of obtaining bio-fuel is based on fermentation, from which is obtained ethanol that can be produced from any biomass, containing carbohydrates (mostly plants that are rich in starch or sugar). The resources for producing ethanol can vary from crops, grown specifically for that purpose, to manure, available in large amounts at cattle farms. Ethanol as a type of bio-fuel can be used as a direct source of energy, or it can also be mixed with conventional gasoline to increase the octane value and lower harmful emissions into the atmosphere.

There are several major types of bio-fuel: solid, liquid and gaseous. Bio-diesel is the example of liquid bio-fuel, while ethanol represents gaseous type of this alternative energy source. Solid bio-fuels such as fuel pellets made from wood chips, sawdust or agricultural wastes are also produced around the world; however, they are not as popular as other types of bio-fuel in view of their higher environment pollution potential. Nowadays, the second and even the third generation of bio-fuels being developed aim at generating energy from non-food crops, cellulose and even certain living algae that produce ethanol during the life activity (Scott et al., 2010). India is also considering algae-based bio-diesel as an option for generation of bio-fuel as it has the potential to produce oil more efficiently than crop plants.

Substitution of conventional gasoline with biodiesel or ethanol in transportation can significantly reduce (up to 100\%) emission of greenhouse gases into the atmosphere. Though carbon dioxide and some other harmful chemicals are also produced while burning bio-fuel, their amount is much lower than the emissions during burning fossil fuels. In addition to being clean for the environment, bio-diesel is also considered to be a better option for diesel engine than conventional diesel fuel. Bio-diesel provides better lubrication and leaves fewer residues in the engine after its burning. Besides, bio-diesel is completely biodegradable and safe.

On the other hand, thoughtless development and wide implementation of any alternative energy source may pose new serious challenges in the economy and environment. In case of bio-fuel, it is necessary to keep in mind that growing popularity of bio-diesel requires more and more land to be used for growing plants as the resource for bio-fuel. However, many of these crops exhaust the soil and can even make it unsuitable for growing foodcrops. Hence, it is of vital importance to evaluate all the pros and cons of every type of alternative energy source before its wide popularization.

Several institutes and companies, including ICT Mumbai, NCL Pune and NIIST Trivandrum are actively pursuing $R \& D$ on ethanol production from ligno-cellulosic waste. The energy output to input ratio is a useful parameter to take stock of the attractiveness of the various processes. Simultaneously, one could ascertain relative attractiveness vis-à-vis the other options such as direct combustion and power generation through gasification. However, it is necessary to quantify the ecological suitability, economic attractiveness and the overall appropriateness factors of different bio-fuel options obtained from different energy feedstock, e.g., biodiesel and briquette from Jatropha or ethanol and bagasse from sugarcane (Bharadwaj et al., 2007). Similarly, more than one type of chargeable energy 
input can be used in producing the bio-fuels, e.g., a different biomass or other renewable energies, fossil fuel or human energy.

Over the last decade, substantial progress has been made towards Jatropha bio-diesel, especially at the downstream end. Jatropha B100 bio-diesel has proved itself adequately as a fuel which can be utilized in mobile and stationary engines without any engine modification and with exceedingly low emissions. This was the successful outcome of the collaboration with Daimler Corporation and others. General Motors (USA) and U.S. Department of Energy seek to ascertain productivity of Jatropha fruiting under realistic conditions prevailing in wasteland and at the same time to carry out a comprehensive life cycle analysis (LCA) under the overall philosophy of "Local use of local produce". This is being done in Gujarat covering both very rocky wastelands (Neswad and Chorvadla in Bhavnagar district) and Gochar land (Halol in Panchmahal district). Further, this study has been carried out with the best germplasm available in India and propagated through cuttings and micropropagation. Use of Jatropha cake is also taken up as a part-substitute of synthetic fertilizers in the spirit of integrated nutrient management. Since the bio-diesel process, now covered through grant of a U.S. patent, is well-established and conforms to stringent emission norms at this point of time, the requirement is assured availability of sufficient biomass. On the other hand, there is a critical need to make a reliable assessment of the true potential of seed biomass from marginal lands.

It has been conclusively established that seedraised plantations lead to greater heterogeneity of performance compared to plantations raised from cuttings of elite mother plants. Hence, there is need to emphasize cultivation through true-to-type plants. This may not, however, be practical, as adequate numbers of cuttings would not be available. Micropropagation is the best answer and a protocol has been developed for micro-propagation.

The Jatropha empty shell briquette has had a profound bearing on Jatropha bio-diesel carbon balance. The energy output to input ratio, now standing at ca. 6 is more than a factor of 2 higher than for soya and rape bio-diesel. The briquettes have been demonstrated to burn satisfactorily in domestic "chuhlas" and boilers. However, no study has been conducted on the characteristics of the smoke. Nothing is also known about the utilization of the ash in the Jatropha field. Hence, these areas need further studies to address the concerns.

\section{Concluding Remarks}

Adoption of AUSC power plants in India, with enhanced steam cycle parameters, i.e. $310 \mathrm{~kg} / \mathrm{cm}^{2}$ and $710^{\circ} / 720^{\circ} \mathrm{C}$, provides an excellent scope for improving gross plant efficiency to better than $46 \%$, and reducing coal consumption per MWe as well as carbon dioxide mitigation potential compared to conventional sub-critical power plants. Although, USC technology for $280 \mathrm{~kg} / \mathrm{cm}^{2}$ and $600^{\circ} \mathrm{C}$ superheater/ reheater steam parameters is considered as mature technology internationally that is ready for adoption, no mature off-the-shelf technology is available for $310 \mathrm{~kg} / \mathrm{cm}^{2}$ and $710^{\circ} / 720^{\circ} \mathrm{C}$ steam parameters. The EU, USA, Japan and China have been putting considerable efforts in developing AUSC technology by co-financing various research projects, targeting materials development, manufacturing, testing and evaluation and demonstration in existing power plants. In view of the above, setting up of an indigenous 800 MWe AUSC demonstration plant, with $310 \mathrm{~kg} / \mathrm{cm}^{2}$ and $710^{\circ} / 720^{\circ} \mathrm{C}$ steam parameters, on a national mission mode, is most opportune, to meet growing energy demands of the country, in an efficient manner.

The integrated gasification combined cycle (IGCC) plants also have the potential of becoming a less expensive carbon capture technology for utilizing low-cost coal as an available fuel source in a carbon constrained world. Similarly, high-temperature biowaste and bio-fuel based plants can conform to stringent emission norms but require quantification of ecological suitability, economic attractiveness and evaluation of overall appropriateness factors of different bio-fuel and bio-waste options obtained from different energy feedstock. 


\section{References}

Bai J W, Liu P P, Zhu Y M, Li X M, Chi C Y, Yu H Y, Xie X S and Zhan Q (2013) Coherent precipitation of copper in Super 304H austenite steel Mater Sci Eng A 584 57-62

Bharadwaj A, Tongia R and Arunachalam V S (2007) Scoping technology options for India's oil security: Part I - ethanol for petrol Curr Sci 92 1071-1077

Coal India Limited (2014) http://www.coalindia.in/

Dietz W, Bader M and Ullrich C (2009) Alloy 617 - An option for high temperature nuclear and conventional power plants, E.ON Engineering GmbH, Gelsenkirchen, Germany

Jayakumar T, Bhaduri A K and Chetal S C (2014) Development of improved high temperature boiler materials for the Indian Advanced Ultra Supercritical thermal power plant technology. In: $10^{\text {th }}$ Liege Conference: Materials for Advanced Power Engineering, (Eds: Lecomte-Beckers J, Dedry O, Oakey J and Kuhn B, Liège) pp 790-799, Belgium

Klenk A, Maile K and Roos E (2010) Advance research for developing and qualifying materials for components.
Proceedings of Conference on Clean Coal India, Confederation of Indian Industries, New Delhi

Logan J, VeneziaJ and Larsen K (2007) Opportunities and challenges for carbon capture and sequestration. Issue No1, World Resources Institute

Maurstad O (2005) An overview of coal based integrated gasification combined cycle (IGCC) technology, MIT LFEE 2005-002 WP, Massachusetts Institute of Technology, Cambridge, MA, USA

Planning Commission, Government of India (2006) Integrated Energy Policy, New Delhi

Scott S A, Davey M P, Dennis J S, Horst I, Howe C J, Lea-Smith D J and Smith A G (2010) Biodiesel from algae: Challenges and prospects Curr Opin Biotechnol 21 277-286

Viswanathan R, Henry J F, Tanzosh J, Stanko G and Shingledecker J (2005) U.S. Program on Materials Technology for USC Power Plants. Advances in Materials Technology for Fossil Power Plants, ASM International

Yongping Y, Guo X and Wang N (2010) Power generation from pulverized coal in China Energy 35 4336-4348. 